\title{
The practice exploration of case teaching mode in the environmental monitoring course teaching
}

\author{
Jing-Ping Wang, Jian Chen, Zheng-Hao Fei, Qing-Hua Dong \\ School of chemistry and environmental engineering, Yancheng Teachers University, Jiangsu, 224007, China \\ Abstract \\ In view of that short and strong practical nature of the core courses in the environmental monitor, and the \\ shortcomings of the case teaching modes of the project completion environmental protection acceptance case in \\ the present individual application project, the project completion acceptance actual case method is set up in the \\ course of the course of the course of environmental monitoring, and the practical case of the project completion \\ acceptance test for the project completion of the project completion of the project is set up in the practical case, \\ which is proved by the practice of the project completion environmental protection acceptance monitoring report \\ of the packaging material of jiangsu shentai packaging material co., LTD. The project has been done with the \\ study of the environment and the teaching model of the project, and it has been applied to the students as the \\ main subject, and it has been taught to do a better job in monitoring the environment after graduation. \\ Keywords Environmental monitoring; The acceptance of the environmental protection project case; The \\ teaching method \\ DOI: $10.7176 / \mathrm{JEP} / 10-6-13$
}

\section{Introduction}

"Environmental monitoring" is a branch of environmental science and engineering. It is an applied course that pays equal attention to theory and practice, and it is an important professional course of environmental related majors ${ }^{[1-2]}$. The main purpose of this course is to enable students to master the basic principles and methods of environmental monitoring, to master the monitoring technology of conventional projects, to learn how to design pollution monitoring programs, and to enable students to have a certain understanding of the basic knowledge of monitoring process quality assurance, as well as to enable students to understand the development trend of new monitoring methods and technologies, which will lay a good foundation for students to engage in environmental protection work and scientific research in the future.

Environmental monitoring is a highly comprehensive curriculum, which covers all environmental media (such as water and wastewater, air and waste gas, solid waste, soil, biological), physical pollution, emergency monitoring of environmental pollution accidents, automatic monitoring and environmental monitoring management and quality assurance. In the course of environmental monitoring, there is more emphases and difficulties in the teaching content of the course, such as: emergency monitoring and noise monitoring of construction project completion acceptance, how to arouse and improve the students' enthusiasm and initiative of the learning of environmental monitoring course through reform of teaching methods and measures, so as to further enhance student analysis and solve the various problems encountered by the environment monitoring process, which is a thought-provoking and research teaching issue ${ }^{[3-6]}$. In view of this, in order to make the student gain better and effectively grasp the relevant theoretical knowledge of the environment monitoring, and improve the practical capability of the students' environment monitoring, this paper puts forward the reform and practice of the teaching method of practical case method in the course of teaching of the environmental monitoring course.

2. Actual case

2.1 Case overview

The project construction site is located in the former taiweier new material co., LTD. (longitude: 120.066705, latitude: 33.312078) of ronghua road in the west of yandu district, yancheng city. The east side of the factory boundary is yandu wind power industrial park, the south side is tianbang feed co., LTD., the west side is ronghua road, and the north side is open space. Jiangsu shentai packing materials limited has a total area of about 100 acres, and the main project of the project is a production line of 50 million square meters of cardboard, and it has built the storage projects, public works, environmental engineering and auxiliary projects.

2.2 Process flow

Purchase of kraft paper, corrugated paper, etc. from the market and corn starch adhesive; .Put a layer of cow paper on the shelf or other original paper, use the preheater to pre-heat it, and then place a single-sided corrugated paper and a layer of cow paper and another piece of paper on the third floor of the corrugated paper; 3 layer of corrugated paper preset and then lay a single layer of corrugated paper and a layer of cardboard to get 5 layers of corrugated paper; 5 layer of corrugated paper preset and then lay a single layer of corrugated paper and a layer of kraft paper to get 7 layers of corrugated paper; After the preparation of corrugated paper, the function of corn flour paste, and then the role of adhesion dryer for steam drying treatment; The dried 
corrugated paper can be divided into cardboard and bound according to the needs of customers to obtain corrugated boxes.

2.3 Production, treatment and discharge of pollutants

2.3.1 Wastewater

The project follows the principle of "shunt shunt, rain shunt", and design and build a drainage network. Rainwater collected by the factory's rainwater pipe network is directly discharged into the nearby river network. After the collection of the project steam condensate, it will be used for the bath water in the urban bathroom, and will not be discharged. No process waste water is produced or discharged, and no canteen and dormitory are built. The waste water collected from the toilet is treated by a septic tank and then used to fertilize vegetables in the plant or plant landscaping. Other domestic sewage is connected to the municipal sewage pipe network and sent to the south city sewage treatment plant for centralized treatment. Project produced wastewater pollution source, treatment and discharge conditions are shown in table 1,

Table 1 production, treatment and discharge of wastewater pollution sources

\begin{tabular}{|c|c|c|c|c|}
\hline \multicolumn{2}{|c|}{ Sources of wastewater } & $\begin{array}{l}\text { Name of } \\
\text { pollutant }\end{array}$ & $\begin{array}{l}\text { Treatment } \\
\text { method }\end{array}$ & $\begin{array}{c}\text { Discharge method and destination of } \\
\text { waste water }\end{array}$ \\
\hline & $\begin{array}{l}\text { The toilet } \\
\text { stool }\end{array}$ & $\begin{array}{c}\text { COD, SS, } \\
\text { ammonia } \\
\text { nitrogen }\end{array}$ & Septic tank & \multirow{2}{*}{$\begin{array}{l}\text { toilet manure septic tank as plant } \\
\text { vegetable fertilization or plant } \\
\text { greening } \\
\text { connected to the municipal sewage } \\
\text { pipe network and sent to the south } \\
\text { city sewage treatment plant for } \\
\text { centralized treatment" }\end{array}$} \\
\hline Sewage & $\begin{array}{c}\text { Other } \\
\text { domestic } \\
\text { sewage }\end{array}$ & $\begin{array}{c}\text { COD, SS, } \\
\text { ammonia } \\
\text { nitrogen }\end{array}$ & / & \\
\hline \multicolumn{2}{|c|}{ rainwater } & / & Direct discharge & $\begin{array}{l}\text { Discharge into river near north } \\
\text { boundary }\end{array}$ \\
\hline
\end{tabular}

\subsubsection{Exhaust}

The project has no process waste gas generation and emission, and the paper products drying process produces a small part of water vapor, which is discharged in an unorganized way. 2.3.3 Noise

The main noise source of the project is the mechanical noise caused by gluing, gluing, drying, shaping and cutting of the carton board production line. Relevant noise sources and emission control are shown in table 2.

Table 2 Major noise sources of the project and control measures table

\begin{tabular}{cccc}
\hline $\begin{array}{c}\text { Serial } \\
\text { number }\end{array}$ & Device name & $\begin{array}{c}\text { Sound source intensity } \\
{[\mathrm{dB}(\mathrm{A})]}\end{array}$ & Control measures \\
\hline & $\begin{array}{c}\text { Carton board production } \\
\text { line }\end{array}$ & 80 & $\begin{array}{c}\text { Reasonable layout, plant sound } \\
\text { insulation, shockproof pad, etc }\end{array}$ \\
\hline
\end{tabular}

\subsubsection{Solid waste}

The solid waste generated in the acceptance project is mainly waste paper scraps and household garbage. Waste paper shall be recycled to the outside, and the domestic rubbish shall be disposed by the environmental sanitation department in a unified way. The production and disposal of various solid wastes are shown in table 3 .

Table 3 Production and disposal of project solid waste

\begin{tabular}{l|l|l|l}
\hline Solid waste named & \multicolumn{1}{|c|}{ Eia yield (t/a) } & \multicolumn{1}{|c}{ Character } & Management measures \\
\hline Waste paper scrap & 20 & Solid & Recycling after sale \\
\hline Household garbage & 5 & Solid & $\begin{array}{l}\text { Sanitation department } \\
\text { unified disposal }\end{array}$ \\
\hline
\end{tabular}

2.4 Acceptance monitoring contents

Due to the small amount of sewage pipe discharge and irregular discharge in the acceptance project, it is impossible to sample and monitor the project and there is no waste gas pollutant generation and discharge. Therefore, this acceptance monitoring only carries out noise monitoring at the factory boundary.

2.4.1 Mmonitoring methods and basis for acceptance projects

The main noise source of the project is the mechanical noise caused by gluing, gluing, drying, shaping and 
cutting of the carton board production line. Relevant noise sources and emission control are shown in table 4 . The monitoring methods and basis are shown in table 5 .

Table 4 Major noise sources of the project and control measures table

\begin{tabular}{c|c|c|c}
\hline $\begin{array}{c}\text { Serial } \\
\text { number }\end{array}$ & Device name & $\begin{array}{c}\text { Sound source intensity } \\
{[\mathrm{dB}(\mathrm{A})]}\end{array}$ & Control measures \\
\hline 1 & $\begin{array}{c}\text { Carton board production } \\
\text { line }\end{array}$ & 80 & $\begin{array}{c}\text { Reasonable layout, plant sound } \\
\text { insulation, shockproof pad, etc }\end{array}$ \\
\hline
\end{tabular}

Table 5 Acceptance monitoring methods and basis table

\begin{tabular}{c|c|c|c}
\hline Type & Monitoring factor & Method name & Method tandard \\
\hline Noise & $\begin{array}{c}\text { Factory boundary } \\
\text { noise }\end{array}$ & $\begin{array}{c}\text { Industrial enterprise factory boundary } \\
\text { environmental noise emission standard }\end{array}$ & GB12348-2008 \\
\hline
\end{tabular}

2.4.2 Monitoring instruments

The monitoring method shall be in accordance with the "environmental noise emission standards for industrial enterprises" (GB12348-2008). See table 6 for details. The monitoring instrument shall be determined by the monitoring unit according to the specification (e.g., AWA5680 sound level meter).

Table 6 Noise emission standards

\begin{tabular}{|c|c|c|c|}
\hline Project & \multicolumn{2}{|c|}{$\begin{array}{l}\text { Emission standard limit value } \\
\qquad(\mathrm{dB})\end{array}$} & Standard basis \\
\hline $\begin{array}{l}\text { Noise of factory } \\
\text { boundary }\end{array}$ & Daytime & $60 \mathrm{~dB}(\mathrm{~A})$ & $\begin{array}{l}\text { "Environmental noise emission standard of } \\
\text { industrial enterprise factory boundary" } \\
\text { (GB12348-2008) } 2 \text { class area standard }\end{array}$ \\
\hline
\end{tabular}

Monitoring was performed by day and night. Frequency monitoring shall be conducted in accordance with relevant provisions of environmental noise emission standards for industrial enterprises (GB12348-2008).

2.5 Monitoring projects and distribution points

The monitoring project is equivalent continuous A sound level (Leq), and 8 monitoring points and frequencies of noise monitoring are arranged outside the perimeter of the company according to the specifications. The current monitoring frequency is $2 \mathrm{~d}$, and the monitoring time is day (6:00-22:00) and night (22:00-6:00).

\section{Formulation of actual case environmental monitoring program}

3.1 Acceptance of monitoring instruments

The multi-function noise analyzer is adopted for the monitoring items, see Fig. 7

Table 7 List of monitoring instruments

\begin{tabular}{cccc}
\hline Name & Model & $\begin{array}{c}\text { number of } \\
\text { instrument }\end{array}$ & $\begin{array}{c}\text { Verification/calibration alid } \\
\text { until }\end{array}$ \\
\hline $\begin{array}{c}\text { Multi-function noise } \\
\text { analyzer }\end{array}$ & AWA5688 & TTE20153110 & October 15, 2018 \\
\hline
\end{tabular}

3.2 Mmonitoring quality control results

The monitoring quality control results are shown in figure 8 . 
Table 8 Quality control results table

\begin{tabular}{c|c|l|l|l|l|c|c}
\hline \multirow{2}{*}{$\begin{array}{c}\text { Monitoring } \\
\text { date }\end{array}$} & $\begin{array}{c}\text { Model and } \\
\text { number of } \\
\text { sound level } \\
\text { meter sound } \\
\text { calibrator }\end{array}$ & $\begin{array}{l}\text { Model and } \\
\text { number of } \\
\text { sound } \\
\text { calibrator }\end{array}$ & $\begin{array}{l}\text { Monitorin } \\
\text { g period of } \\
\text { time }\end{array}$ & $\begin{array}{c}\text { Monitorin } \\
\text { g of the } \\
\text { former }\end{array}$ & $\begin{array}{c}\text { After } \\
\text { monitoring }\end{array}$ & $\begin{array}{c}\text { Ceviation } \\
\text { of } \\
\text { indicated } \\
\text { value }\end{array}$ & $\begin{array}{c}\text { Whethe } \\
\mathrm{r} \\
\text { qualifie } \\
\mathrm{d} \text { or not }\end{array}$ \\
\hline \multirow{2}{*}{2018.15} & $\begin{array}{c}\text { AWA5688 } \\
\text { multifunctional } \\
\text { noise analyzer } \\
\text { ty-22 }\end{array}$ & $\begin{array}{c}\text { AWA6221B } \\
\text { TY-25 }\end{array}$ & Daytime & 93.8 & 93.8 & 0 & $\begin{array}{c}\text { qualifie } \\
\mathrm{d}\end{array}$ \\
\hline & $\begin{array}{c}\text { AWA5688 } \\
\text { multifunctional } \\
\text { noise analyzer } \\
\text { ty-22 }\end{array}$ & $\begin{array}{c}\text { AWA6221B } \\
\text { TY-25 }\end{array}$ & Daytime & 93.8 & 93.8 & 0 & $\begin{array}{c}\text { qualifie } \\
\mathrm{d}\end{array}$ \\
\hline
\end{tabular}

3.3 Results and evaluation of noise monitoring at factory boundaries

During monitoring, daytime boundary noise during acceptance monitoring is in accordance with the standard of class 2 area of environmental noise emission standard at boundary of industrial enterprises (gb123482008). Specific monitoring results are shown in table 9.

Table 9 Noise monitoring results and evaluation table of factory boundary

\begin{tabular}{|c|c|c|}
\hline \multirow{2}{*}{ Measuring point } & \multicolumn{2}{|c|}{ Daytime $[\mathrm{dB}(\mathrm{A})]$} \\
\hline & October 15, 2018 & October 16, 2018 \\
\hline Z1 (East plant out $1 \mathrm{~m}$ ) & 56 & 57 \\
\hline Z2(East plant out 1m) & 56 & 57 \\
\hline Z3(South plant out $1 \mathrm{~m}$ ) & 58 & 58 \\
\hline Z4(South plant out $1 \mathrm{~m}$ ) & 57 & 58 \\
\hline Z5(West plant out $1 \mathrm{~m}$ ) & 57 & 58 \\
\hline Z6((West plant out $1 \mathrm{~m})$ & 58 & 57 \\
\hline Z7(North plant out $1 \mathrm{~m})$ & 57 & 59 \\
\hline Z8(North plant out $1 \mathrm{~m}$ ) & 58 & 59 \\
\hline The maximum & \multicolumn{2}{|c|}{59} \\
\hline Standard values & \multicolumn{2}{|c|}{$\leq 60$} \\
\hline Evaluation & \multicolumn{2}{|c|}{ Up to standard } \\
\hline Note & $\begin{array}{l}\text { Meteorological parameters duri } \\
\text { Weather: loudy; Temper } \\
\mathrm{kPa} \text {; Wind direction: north win }\end{array}$ & $\begin{array}{l}\text { dity: } 43 \% ; \text { Pressure: } 103.0 \\
-3.1 \mathrm{~m} / \mathrm{s} .\end{array}$ \\
\hline
\end{tabular}

As can be seen from the monitoring results in table 9, the $2 \mathrm{~d}$ noise measurement points at all boundaries of this project can meet the requirements of noise emission standards at the factory boundary of industrial enterprises (GB12348-2008). There is no excessive emission, and the noise emission at the standard has little impact on the surrounding environment

\section{Conclusion}

In the course of the teaching class system that has been used throughout the environment, it has broken the drawbacks of the "theory and practice" of "theory and practice", and on the other hand, the theoretical knowledge of the textbook is not too abstract and boring, so that the content of teaching is more realistic, so that the students are motivated and motivated by the knowledge of the environment, which is good for the student, which is good for the students, and so that they can do a better job of doing environmental monitoring in the first place. 
Acknowledgement

The research is supported by a Project Funded by the brand professional project form Yancheng teachers university (2016), the teaching reform and practice of medicinal chemistry (17YCTCJY011) 、 (12YCTCJY011)and A Project Funded by the Excellent Specialties Program Development of Jiangsu Higher Education Institutions (PPZY2015B113).

\section{References}

[1] Yi Li, Xu-Qiang Luo, Hong-Yan Yang, et al. (2014).Reflections on environmental monitoring course teaching in colleges and universities [J].Journal of guangdong chemical industry.41 (21) : 246-247.

[2] Shuang-Mei Tong. (2014).Discussion on teaching reform of environmental monitoring course in universities [J]. Journal of anhui agricultural science.20 (12) : 153-155.

[3] Hui Liu, Wang-Mei Lao, Qi-Kun Ma, et al.(2013). Application of project teaching in environmental monitoring course [J]. Journal of industrial technology and vocational education.11 (1) : 43-44.

[4] Jun-Xia Xiao, Xian-Ge Wu. (2010).Research and practice of environmental monitoring course teaching reform [J]. Journal of guangdong chemical industry .38 (7) : 270-272.

[5] Chun-Ming Chen.(2013).Application of the theory and practice teaching method in the teaching of environmental monitoring course -- a case study of "emergency monitoring of sudden water pollution accidents" [J]. Journal of guangdong chemical industry.40 (16) : 234-235.

[6] Yu-Hong $\mathrm{Xu}$. (2010).Analysis of environmental sensitive point noise monitoring in project completion acceptance [J]. Journal of environment and sustainable development,35 (1) : 58-60. 